\title{
RANCANG BANGUN SISTEM INFORMASI GEOGRAFIS BERBASIS WEB DAN ANDROID UNTUK PEMETAAN INDUSTRI KECIL DAN MENENGAH DI KOTA MATARAM
}

\author{
(Designing Web and Android Based Geographic Information System for Mapping \\ Small and Medium Industry in Mataram City)
}

Deo Marta Dipayana*, Moh. Ali Albar, Ida Bagus Ketut Widiartha

Teknik Informatika, Fakultas Teknik, Universitas Mataram

Jl. Majapahit 62, Mataram, Lombok NTB, INDONESIA

Email: deo.dipayana7@gmail.com,mohalialbar@unram.ac.id,widi@unram.ac.id

\begin{abstract}
Small and Medium Industries (SMIs) have a very important role as a driver of the economy in Indonesia because SMIs can function as a provider of employment for a number of people who are not accommodated in the formal sector. SMIs also contributes to the formation of Gross Domestic Product (GDP) and as a source of foreign exchange. However, SMIs experienced obstacles in the fields of marketing, business networks, and information technology. In realizing an independent and developing SMIs, a supporting media is needed which can later be useful as a tool to introduce SMIs to the wider community and align it with other business actors. In addition, the government also needs a media that can be used for licensing data collection, taxes, and as a tool to monitor the development of SMIs. In this case a geographic and web-based geographic information system has been built to meet the need for information on SMIs in the city of Mataram. It is hoped that this system can help the community and the government to find out the information needed easily, quickly, and accurately. Based on the results of the Mean Opinion Score, it shows that the average rating of respondents of website users on the system agrees and strongly agrees to agree worth 67.50\%. While the average rating of respondents of mobile users to the system agree and strongly agree is worth $78.33 \%$.
\end{abstract}

Keywords: geographic information system, small and medium industries, SMIs, web, android, Mataram city.

*Penulis korespondensi

\section{Pendahuluan}

Industri Kecil dan Menengah (IKM) merupakan industri yang memiliki skala industri yang terbilang kecil dan menengah. IKM memiliki peran yang sangat penting sebagai penggerak perekonomian di Indonesia karena IKM dapat berfungsi sebagai penyedia lapangan kerja bagi sejumlah orang yang tidak tertampung di sektor formal. IKM juga turut berkontribusi terhadap pembentukan Produk Domestik Bruto (PDB) dan sebagai sumber penghasil devisa negara. IKM sedikit berbeda dengan Usaha Mikro Kecil dan Menengah (UMKM), dimana IKM memproduksi sendiri produk barang atau jasa yang akan dipasarkan baik dalam bentuk barang setengah jadi maupun barang jadi. Sedangkan UMKM tidak memproduksi suatu produk barang atau jasa, melainkan hanya memasarkan produk yang dipasok dari pihak lain. Dalam aktivitas ekonominya UMKM memiliki hubungan yang sangat erat dengan IKM, dimana sering kali masyarakat yang ingin membuka suatu UMKM baru memerlukan IKM sebagai pemasok produk yang akan dipasarkan, sedangkan IKM memerlukan UMKM sebagai salah satu pasar mereka.

Namun, IKM sering mengalami hambatan dalam bidang pemasaran, jaringan bisnis, dan teknologi informasi. Pada dasarnya IKM memiliki hambatan yang berkaitan dengan rendahnya kualitas sumber daya manusia (SDM), rendahnya teknologi informasi yang dimiliki, lemahnya manajemen usaha, dan tidak adanya suatu media yang dapat memudahkan Dinas Perindustrian untuk memantu perkembangan IKM, serta rendahnya akses terhadap sumber pembiayaan dan pasar, sehingga banyak masyarakat yang masih tidak mengetahui keberadaan IKM dan produk apa saja yang dihasilkan oleh IKM tersebut.

Dalam mewujudkan IKM yang mandiri dan berkembang, diperlukan suatu media pendukung yang nantinya dapat berguna sebagai alat untuk memperkenalkan IKM kepada masyarakat luas dan mensejajarkan IKM dengan pelaku usaha lainnya. Selain itu Dinas Perindustrian juga memerlukan suatu 
media yang dapat digunakan untuk keperluan pendataan perizinan dan sebagai alat untuk memantau perkembangan IKM. Dalam hal ini pemanfaatan teknologi informasi dapat digunakan sepenuhnya di dalam dunia usaha, salah satunya adalah berbentuk website dan aplikasi mobile guna mempromosikan perusahaan dan produk yang dihasilkan serta informasi mengenai lokasi IKM tersebut.

Sistem Informasi Geografis (SIG) atau Geographic Information System (GIS) akhir-akhir ini mengalami perkembangan yang berarti seiring kemajuan teknologi informasi. Sistem Informasi Geografis adalah sebuah sistem yang didesain untuk menangkap, menyimpan, memanipulasi, menganalisa, mengatur dan menampilkan seluruh jenis data geografis [1]. Penggunaan data geografis dapat mengatasi masalah di segala bidang, salah satunya dalam bidang ekonomi. SIG dapat digunakan untuk mengetahui persebaran industri kecil dan menengah.

Oleh karena itu dibutuhkan suatu sistem informasi geografis industri kecil dan menengah yang dapat memperkenalkan IKM kepada masyarakat luas dan memberikan informasi mengenai lokasi berbagai macam industri kecil dan menengah yang ada di kota Mataram. Pada sistem informasi tersebut diperlukan suatu fitur yang dapat menggambarkan persebaran IKM yang ada di kota Mataram sehingga hal tersebut dapat mempermudah masyarakat dan Dinas Perindustrian dalam memperoleh informasi yang dibutuhkan, serta dapat menunjukkan rute menuju IKM yang dituju oleh pengguna. Selain itu, dibutuhkan juga suatu fitur yang dapat memfasilitasi pemilik usaha atau industri untuk mendaftarkan usaha mereka agar Dinas Perindustrian mudah dalam melakukan pengawasan. Dalam konteks pemakaiannya sistem ini dibuat berbasis website dan aplikasi mobile berbasis android, sehingga dapat diakses kapanpun dan dimanapun. Hal ini dimaksudkan agar masyarakat yang ingin memanfaatkannya dapat dengan mudah untuk mengaksesnya.

Untuk mengatasi permasalahan di atas, maka dalam penelitian ini diangkat judul "Rancang Bangun Sistem Informasi Geografis Berbasis Web dan Android untuk Pemetaan Industri Kecil dan Menengah di Kota Mataram". Hasil dari penelitian ini diharapkan dapat membantu masyarakat untuk mengetahui informasi mengenai industri kecil dan menengah di kota Mataram dengan mudah, cepat, dan akurat.

\section{TINJAUAN PUSTAKA}

Adapun penelitian yang digunakan sebagai acuan dalam melakukan penelitian yaitu sebagai berikut:

a. "Rancang Bangun Sistem Informasi Geografis Usaha Mikro, Kecil Dan Menengah (UMKM) Sebagai Media Pemetaan, Promosi dan Pemesanan di Kota Mataram Berbasis Web". Penelitian ini bertujuan untuk membangun suatu sistem informasi berbasis geografis sebagai media pemetaan, media promosi, media pemasaran serta pemesanan produk-produk UMKM yang ada di Kota Mataram berbasis web. Sistem ini menyediakan fasilitas untuk mengetahui UMKM yang ada di Kota Mataram dengan fitur informasi geografis, menyediakan berbagai informasi seputar dunia UMKM, menjadi sarana promosi UMKM yang ada di Kota Mataram, membantu para pengusaha sebagai media pemasaran $e$ commerce dan menjadi media antara UMKM dan konsumen untuk fasilitas pemesanan produk UMKM. Namun pada sistem tersebut masih terdapat kekurangan, yaitu tidak adanya fitur pencarian rute yang dapat digunakan untuk menampilkan saran rute yang dapat ditempuh oleh calon konsumen menuju ke IKM tujuan [2].

b. Penelitian tentang pemetaan IKM juga pernah dibuat dalam jurnal yang berjudul "Sistem Informasi Geografis Berbasis Web untuk Pemetaan Industri Kecil dan Menengah di Kabupaten Bantul". Sistem ini merupakan alat bantu untuk menyampaikan informasi sekaligus sebagai media promosi mengenai persebaran IKM di Kabupaten Bantul. Sistem ini dapat memberikan informasi yang akurat mengenai lokasi IKM yang ada di Kabupaten Bantul yang diimplementasikan pada SIG berbasis web. Namun, pada sistem tersebut masih terdapat kekurangan seperti kurangnya keterangan-keterangan pendukung pada wilayah peta yang dibuat.SIG ini dikembangkan dengan menggunakan ArcView. Metode penelitian yang digunakan adalah metode pengembangan sistem. Aplikasi ini memanfaatkan database MySQL sebagai database server, menggunakan bahasa pemrograman PHP, dan dibantu dengan SVG Viewer untuk menampilkan peta [3].

c. Penelitian tentang pemetaan persebaran IKM berbasis android pernah dibuat dalam jurnal yang berjudul "Sistem Informasi Geografis Berbasis Android Untuk Pemetaan Industri Kecil di Kabupaten Bantul". Sistem ini dibuat dengan tujuan untuk memetakan persebaran industri kerajinan yang ada di kabupaten Bantul yang dapat 
memudahkan masyarakat dalam memperoleh informasi mengenai persebaran lokasi industri kecil yang ada di daerah tersebut. Sistem ini mampu menampilkan lokasi pengguna dengan industri kerajinan beserta informasi industri kerajinan. Sistem juga dapat menampilkan industri kerajinan pada peta virtual Google Maps, dan setiap industri yang dipilih disediakan fasilitas map, galeri, dan dial up. Namun, terdapat kekurangan pada sistem ini yaitu tidak adanya fitur untuk menampilkan rute yang dapat ditempuh oleh pengguna untuk menuju ke lokasi IKM [4].

Penelitian tentang pemetaan IKM berbasis android juga pernah dibuat dalam jurnal yang berjudul "Rancang Bangun Sistem Informasi Geografis Industri Kecil dan Menengah Kabupaten Deli Serdang Berbasis Android". Sistem tersebut dibuat dengan tujuan untuk memudahkan masyarakat kabupaten Deli Serdang dalam memperoleh informasi lokasi IKM yang ada di daerah tersebut. Sistem tersebut dibuat berbasis android untuk memudahkan masyarakat dalam mengaksesnya. Selain itu, sistem tersebut juga mempunyai fitur yang dapat menunjukkan rute yang dapat ditempuh oleh pengguna untuk menuju ke suatu IKM. Namun, pada sistem tersebut masih terdapat kekurangan, yakni tidak ada suatu fitur yang dapat memfasilitasi para pemilik usaha untuk mendaftarkan IKM mereka ke dalam sistem [5].

\section{Metode Penelitian}

RESTful Web Service dibangun menggunakan bahasa pemrograman PHP dan basis data MySQL untuk menyimpan data konten-konten penunjang aplikasi dan disimulasikan menggunakan server lokal. Pembangunan sistem informasi geografis IKM kota Mataram ini terdiri dari dua buah sistem yang berbeda yaitu aplikasi website yang dapat diakses oleh admin dan aplikasi mobile yang dapat diakses oleh pemilik IKM dan masyarakat. Kedua sistem ini saling terintegrasi satu sama lain. Gambaran arsitektur yang akan dibangun dapat dilihat pada Gambar 1.

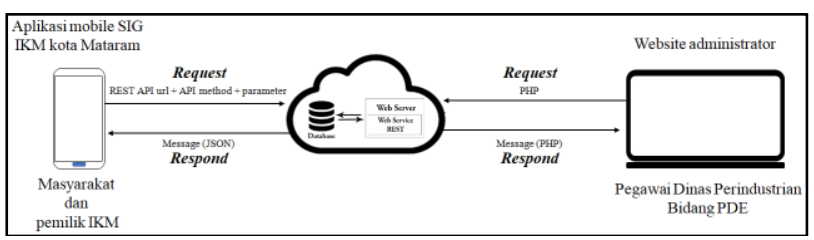

Gambar 1. Arsitektur web service SIG IKM kota Mataram

Web service pada sistem ini nantinya akan bertugas sebagai controller yang akan menangani request dari website dan aplikasi mobile, hasil dari request tersebut dikirim ke model dimana model akan menangani request tersebut kedalam database. Hasil dari proses tersebut ditangani kembali oleh controller dan akan mengirimkan respond dari hasil tersebut ke view, dimana pada sistem ini view untuk website dibuat dalam bentuk PHP dan view untuk aplikasi mobile dibuat dalam bentuk JSON.

\subsection{Metode Pengembangan Sistem}

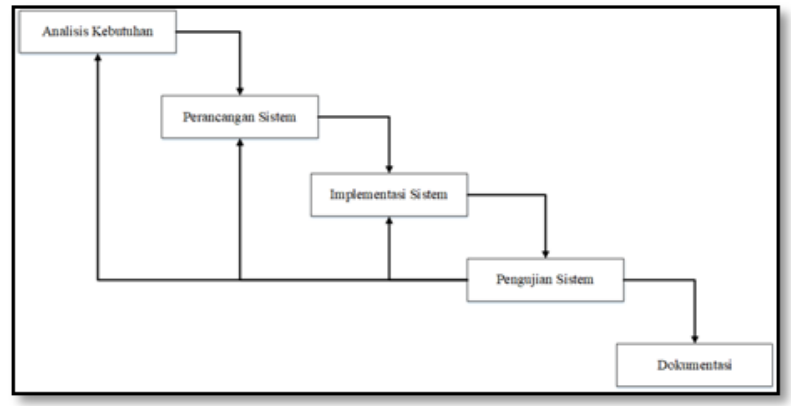

Gambar 2. Tahapan pengembangan sistem dengan model waterfall

Proses pengembangan sistem menggunakan metode waterfall yang terdiri dari lima tahap, yaitu analisa kebutuhan, perancangan sistem, implementasi sistem, pengujian sistem, dan dokumentasi.

\subsubsection{Analisa Kebutuhan}

Tahap pertama dalam pembuatan sistem informasi geografis industri kecil dan menengah di kota Mataram adalah tahap pendefinisian kebutuhan sistem. Pada tahap ini akan dilakukan pengumpulan data dan penjabaran berbagai kebutuhan sistem serta user sehingga sistem dapat dirancang dengan baik dan dapat berjalan optimal.

1. Pengumpulan Data

Tahap pengumpulan data adalah mengumpulkan seluruh data yang diperlukan dalam pembuatan sistem informasi geografis industri kecil menengah di kota Mataram yang diperoleh dari Dinas Perindustrian Provinsi Nusa Tenggara Barat sebagai data acuan utama. Data-data tersebut dapat berupa nama industri, nama pemilik, alamat industri, jumlah tenaga kerja, nilai investasi, dan produk yang dihasilkan.

2. Penjabaran Kebutuhan Sistem

Penjabaran kebutuhan sistem adalah tahapan untuk menjabarkan dan menganalisis berbagai perilaku sistem. Kebutuhan sistem harus sesuai dengan sistem tujuan yang akan dibangun dan harus dapat memenuhi kebutuhan end user yang akan menggunakan sistem tersebut. Kebutuhan 
sistem yang telah dianalisa adalah sebagai berikut:
a. Sistem dapat memberikan informasi mengenai persebaran industri kecil dan menengah yang ada di kota Mataram.
b. Sistem dapat mendata lokasi IKM, jenis usaha, perizinan, dan lain-lain secara online.
c. Sistem dapat melakukan filtering data IKM berdasarkan kategori tertentu seperti cabang industri maupun produk yang ditawarkan.
d. Sistem dapat memberikan informasi pendukung lainnya yang berkaitan dengan IKM kepada masyarakat.
e. Sistem dapat menampilkan saran rute yang dapat ditempuh untuk menuju IKM tujuan.

3. Penjabaran Kebutuhan Pengguna

Penjabaran kebutuhan pengguna merupakan suatu tahapan untuk menjabarkan dan menganalisis kebutuhanpengguna terhadap sistem yang akan dibuat. Dalam sistem informasi geografis industri kecil dan menengah di kota Mataram ini, yang bertindak sebagai end user adalah Dinas Perindustrian Provinsi Nusa Tenggara Barat, pemilik IKM dan masyarakat umum. Berbagai kebutuhan end user dapat didefinisikan sebagai berikut:

a. Masyarakat memerlukan suatu media yang dapat menyediakan informasi mengenai persebaran IKM yang ada di kota Mataram yang mudah diakses.

b. Pemilik IKM memerlukan suatu media yang dapat digunakan untuk mendaftarkan IKM yang mereka miliki ke Dinas Perindustrian.

c. Dinas Perindustrian memerlukan suatu media yang dapat digunakan untuk mengawasi dan menganalisa perkembangan IKM di kota Mataram.

\subsubsection{Perancangan Sistem}

\section{a. Use Case Diagram}

Use case mendeskripsikan interaksi tipikal antara para pengguna sistem dengan sistem itu sendiri, dengan memberi sebuah narasi tentang bagaimana sistem tersebut digunakan seperti yang terdapat pada Gambar 3.

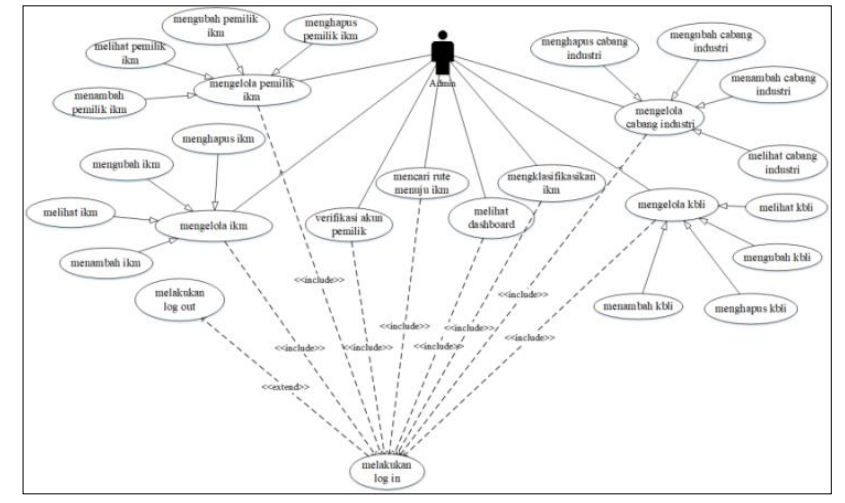

Gambar 3. Use Case Diagram SIG berbasis web untuk admin

Sedangkan di sisi android, use case diagram dapat digambarkan seperti yang terdapat pada Gambar 4.

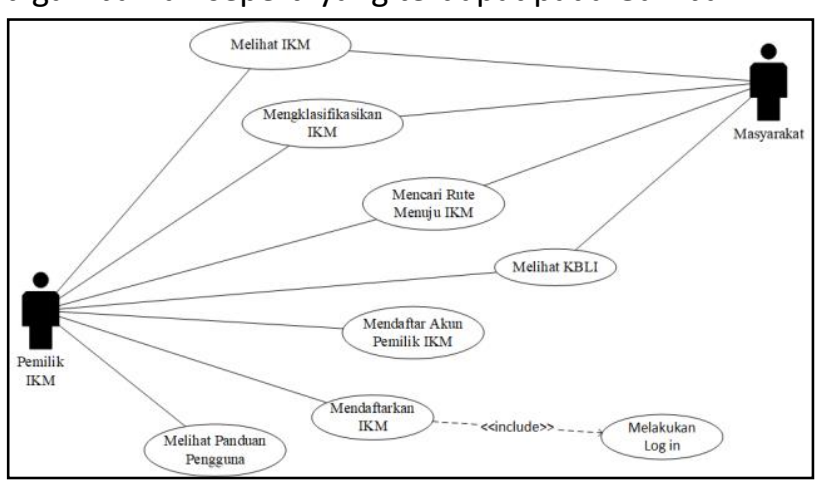

Gambar 4. Use Case Diagram SIG berbasis android untuk masyarakat dan pemilik IKM

\section{b. Class diagram}

Pada sistem yang akan dibangun terdapat sepuluh kelas yaitu Cl_Controller, Cl_Model, Ikm, Kbli, Cabang_Industri, Auth, RESTclient, M_Admin, dan RESTmodel, serta IkmApp.

Hubungan antar kelas tersebut adalah sebagai berikut:

1. Kelas Cl_Controller dan Cl_Model merupakan kelas yang disediakan oleh Codeigniter. Terdapat kelas-kelas seperti Ikm, Kbli, Cabang_Industri, Auth, dan RESTserver yang merupakan kelas turunan dari kelas $\mathrm{Cl} \_$Controller.

2. Kelas M_Admin dan RESTmodel merupakan turunan dari kelas Cl_Model yang akan digunakan dalam proses manipulasi atau management data di database.

3. Kelas RESTclient merupakan kelas yang akan digunakan untuk menjalankan fungsi web service pada sistem ini.

4. IkmApp merupakan kelas yang akan dibangun di sisi android untuk bertindak sebagai client 
dari web service yang melakukan request ke RESTserver.

Rancangan class diagram dari sistem yang akan dibangun dapat dilihat pada Gambar 5.

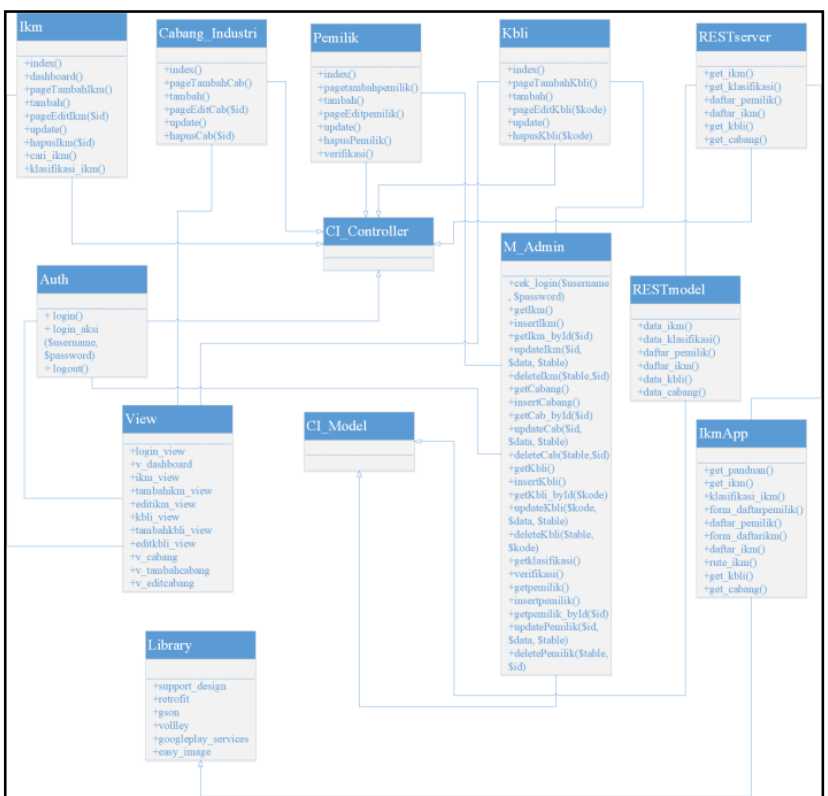

Gambar 5. Class diagram

\subsubsection{Perancangan Database}

Berikut rancangan ERD untuk system informasi geografis industri kecil dan menengah.

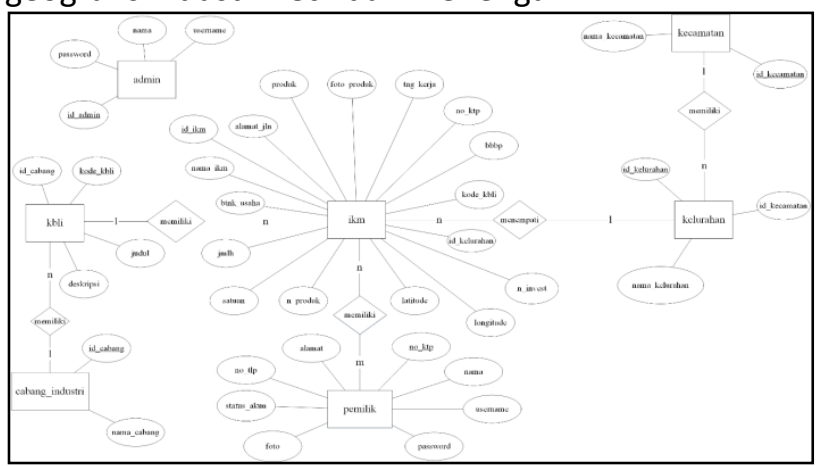

Gambar 6. Rancangan Entity Relationship Diagram

\subsubsection{Rancangan Implementasi Sistem}

Tahapan selanjutnya adalah implementasi dari rancangan sistem yang telah dilakukan ke dalam bentuk bahasa pemrograman (coding). Proses pembuatan sistem berbasis web akan menggunakan framework Codeigniter yang merupakan suatu framework dalam bahasa pemrograman PHP. Sedangkan untuk proses pembuatan aplikasi mobile berbasis android akan menggunakan Android Studio.

\subsubsection{Rancangan Pengujian Sistem}

Setelah tahap coding dan implementasi selesai dilakukan, maka tahap selanjutnya adalah melakukan pengujian terhadap sistem. Pengujian dilakukan dengan melihat secara keseluruhan dari fungsi-fungsi yang telah selesai dan membandingkan tingkat kesesuaian sistem dengan rancangan yang telah dibuat sebelumnya. Apabila masih terdapat bagian yang perlu diperbaiki, maka proses pengerjaan akan kembali ke tahap coding dan implementasi sistem.

1. Pengujian Black Box

Pengujian black box merupakan pengujian untuk mengetahui apakah semua fungsi perangkat lunak telah berjalan semestinya sesuai dengan kebutuhan fungsional yang telah didefinisikan.

2. Pengujian Mean Opinion Score (MOS)

Kuisioner adalah suatu teknik pengumpulan informasi yang memungkinkan untuk mempelajari karakteristik dari sistem yang telah dibuat. Kuisioner melibatkan responden di dalam sistem untuk memberikan penilaian subjektif dengan metode MOS. Adapun standar penilaian MOS dapat dilihat pada Tabel I. dibawah ini:

tABEl I. TABel Pengujian MOS

\begin{tabular}{|c|c|}
\hline Nilai MOS & Tingkat Kepuasan \\
\hline 5 & Sangat Baik \\
\hline 4 & Baik \\
\hline 3 & Cukup Baik \\
\hline 2 & Tidak Baik \\
\hline 1 & Buruk \\
\hline
\end{tabular}

\section{Hasil dan Pembahasan}

\subsection{Implementasi}

Pada bab ini akan diuraikan hasil implementasi dari sistem yang telah dibangun berdasarkan perancangan yang ada dan melakukan pengujian sistem.

\subsubsection{Implementasi Database}

Berikut ini merupakan hasil implementasi rancangan ERD ke dalam bentuk tabel database yang dapat dilihat pada Gambar 7. 


\begin{tabular}{|c|c|c|}
\hline & Tabel $\Delta$ & Tindakan \\
\hline$\square$ & admin & $\hat{\imath}$ 国 Jelajahi ${ }^{2}$ Struktur \\
\hline$\square$ & cabang_industri & 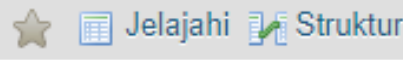 \\
\hline$\square$ & ikm & 饭 国 Jelajahi 郎 Struktur \\
\hline$\square$ & kbli & 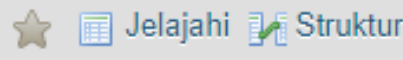 \\
\hline$\square$ & kecamatan & 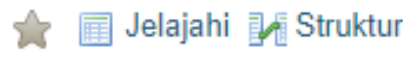 \\
\hline$\square$ & kelurahan & 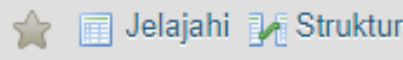 \\
\hline$\square$ & pemilik & 상 膡 Jelajahi 郎 Struktur \\
\hline & 7 tabel & Jumlah \\
\hline
\end{tabular}

Gambar 7. Daftar tabel yang terdapat pada database ikmgis

\subsubsection{Implementasi Class}

Pembangunan class pada sistem informasi geografis berbasis web dan android untuk pemetaan industri kecil dan menengah di kota Mataram mataram ini dibagi menjadi dua bagian yaitu pembangunan class untuk website dan pembangunan class untuk menangani request dari aplikasi mobile. Berdasarkan perancangan class diagram yang telah dilakukan sebelumnya, pengimplementasian class yang dilakukan sudah sesuai dengan perancangan tersebut. Dalam implementasinya, class dibangun untuk menangani request dari client berbasis website maupun client dari aplikasi mobile berdasarkan struktur yang dimiliki oleh framework Codelgniter yaitu menggunakan konsep MVC (Model, View, Controller). Selain itu, untuk membuat suatu request dari aplikasi mobile, maka class dibangun menggunakan Android Studio yang memanfaatkan bahasa pemrograman Java.

\subsubsection{Implementasi Interface}

a. Interface Administrator

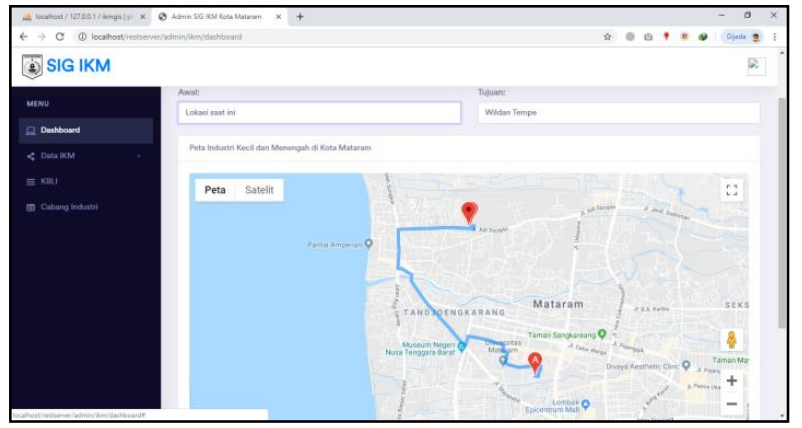

Gambar 8. Interface halaman dashboard
Pada Interface Administrator (Gambar 8) terdapat peta yang menampilkan sebaran IKM yang ada di kota Mataram. Selain itu, terdapat fitur yang dapat menampilkan saran rute perjalanan menuju IKM tujuan.

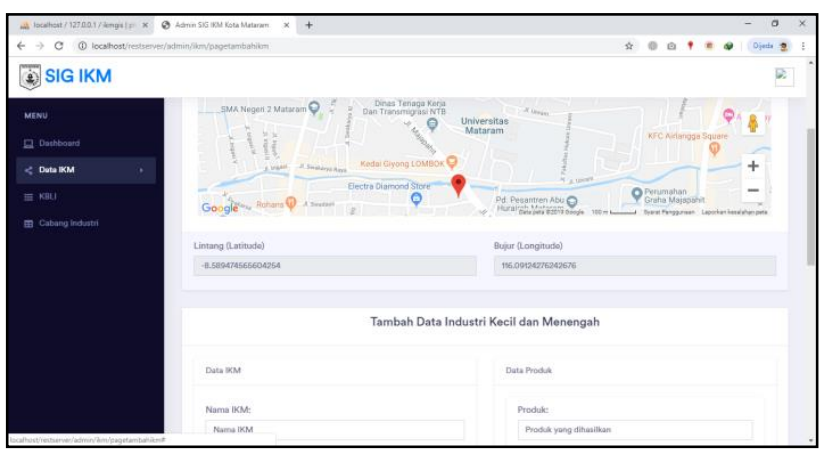

Gambar 9. Interface halaman form IKM

Halaman form IKM (Gambar 9) ini digunakan untuk menangani keperluan proses menambahkan maupun mengubah data IKM.

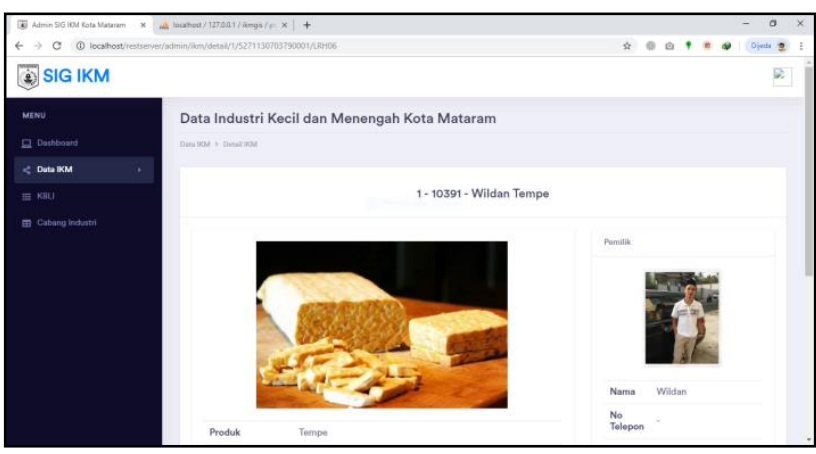

Gambar 10 Interface halaman detail data IKM

Halaman detail data IKM (Gambar 10) merupakan halaman yang digunakan untuk menampilkan data suatu IKM secara rinci, lengkap dengan data pemiliknya.

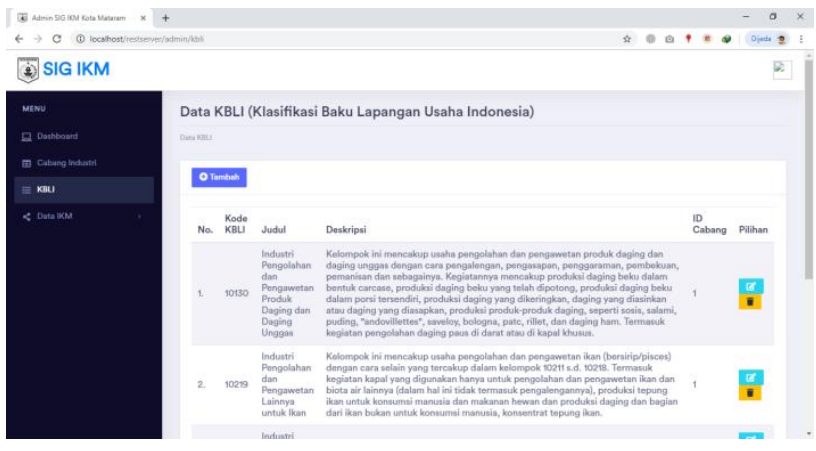

Gambar 11. Interface halaman KBLI

Pada halaman ini ditampilkan informasi tentang kode KBLI beserta deskripsinya (lihat Gambar 11). 
b. Interface menu utama pada aplikasi mobile

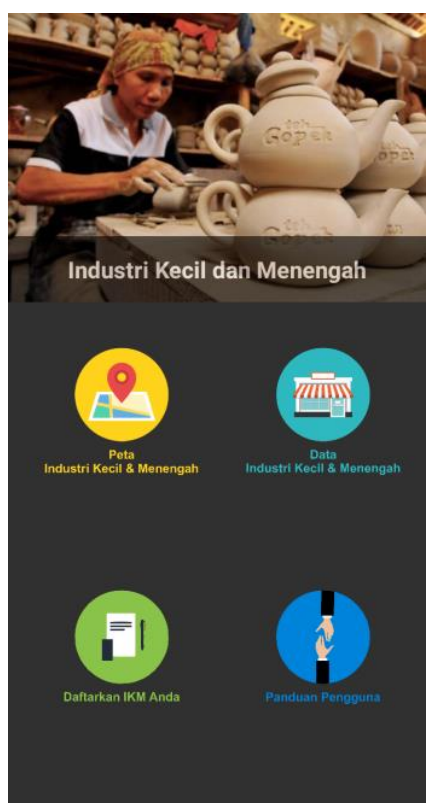

Gambar 12. Interface menu utama

Pada interface menu utama (Gambar 12) terdapat empat menu yang dapat digunakan untuk memperoleh informasi mengenai IKM diantaranya, menu peta IKM, menu data IKM, menu pendaftaran IKM, dan menu panduan pengguna.

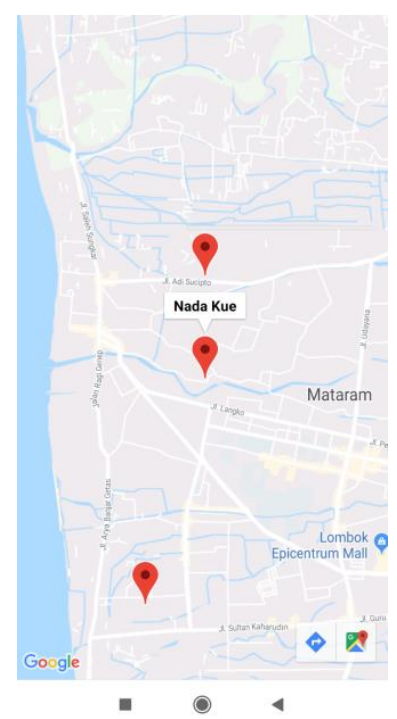

Gambar 13. Interface menu peta IKM

Pada interface menu peta IKM (Gambar 13) ini akan menampilkan peta sebaran IKM yang ada di kota Mataram. Pada saat pengguna menekan map marker maka akan dimunculkan sebuah info window berupa informasi nama IKM pada map marker yang dipilih tersebut.
Selain itu, pada halaman peta IKM ini terdapat fitur yang dapat digunakan untuk menampilkan saran rute terdekat untuk menuju ke suatu IKM (lihat Gambar 14).

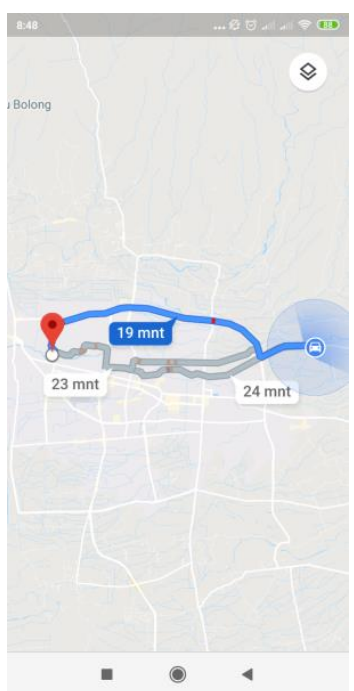

Gambar 14. Interface fitur pencarian rute

\section{KeSIMPULAN DAN SARAN}

\subsection{Kesimpulan}

Berdasarkan penelitian dan pembangunan sistem yang telah dilakukan, dapat ditarik beberapa kesimpulan dalam "Rancang Bangun Sistem Informasi Geografis Berbasis Web dan Android untuk Pemetaan Industri Kecil dan Menengah di Kota Mataram" diantaranya:

1. Pembuatan sistem informasi geografis berbasis web dan android pada tugas akhir ini dapat memberikan informasi tentang persebaran lokasi IKM yang ada di kota Mataram secara real-time, sehingga dapat memudahkan baik masyarakat, pemilik IKM maupun Dinas Perindustrian untuk memperoleh informasi yang dibutuhkan.

2. Menu pendaftaran IKM memudahkan para pemilik IKM dalam mendaftarkan IKM yang mereka miliki ke Dinas Perindustrian untuk dapat memperoleh Tanda Daftar Industri (TDI).

3. Fitur pencarian rute pada aplikasi ini membantu pengguna untuk dapat menemukan saran rute terdekat yang dapat ditempuh untuk menuju ke suatu IKM.

4. Hasil pengujian black box menunjukkan bahwa seluruh fungsi baik pada sistem informasi berbasis website maupun aplikasi mobile telah berjalan sesuai dengan yang diharapkan.

5. Berdasarkan hasil Mean Opinion Score menunjukkan bahwa rata-rata penilaian 
responden pengguna website terhadap sistem menyatakan setuju dan sangat setuju setuju bernilai $67,50 \%$. Sedangkan rata-rata penilaian responden pengguna mobile terhadap sistem menyatakan setuju dan sangat setuju bernilai $78,33 \%$

\subsection{Saran}

Dikarenakan masih banyak kekurangan dari penulis dalam mengembangkan sistem ini, terdapat beberapa saran untuk dapat membuat sistem ini menjadi lebih baik pada waktu yang akan datang, diantaranya:

1. Pada menu peta geografis sebaiknya ditambahkan fitur yang dapat menampilkan saran IKM yang berada di dekat pengguna dalam radius dan kategori tertentu untuk memudahkan pengguna dalam melakukan pencarian IKM.

2. Pada bagian administrator sebaiknya ditambahkan fitur yang dapat menentukan suatu daerah sebagai sentra IKM berdasarkan pada pertimbangan-pertimbangan tertentu.

Untuk lebih mempromosikan IKM yang ada, sebaiknya ditambahkan suatu fitur yang dapat menampilkan informasi mengenai event yang digelar oleh Dinas Perindustrian yang berkaitan dengan IKM.

\section{UCAPAN TERIMA KASIH}

Ucapan terima kasih diberikan kepada Allah S.W.T., kedua orang tua, dan seluruh pihak yang telah membantu dalam penyelesaian penelitian ini.

\section{DAFTAR PUSTAKa}

[1] E. Irwansyah., "Sistem Informasi Geografis: Prinsip Dasar dan Pengembangan Aplikasinya", Yogyakarta: Digibooks, 2013.

[2] N. R. Sudianjaya, "Rancang Bangun Sistem Informasi Geografis Usaha Mikro, Kecil Dan Menengah (UMKM) Sebagai Media Pemetaan, Promosi dan Pemesanan di Kota Mataram Berbasis Web", Jurnal Penelitian Program Studi Teknik Informatika,
Fakultas Teknik Universitas Mataram, 2016.

[3] B. M. Jati, "Sistem Informasi Geografis Berbasis Web untuk Pemetaan Industri Geografis di Kabupaten Bantul", Jurnal Penelitian Program Studi Teknik Informatika, Fakultas Sains dan Teknologi UIN Sunan Kalijaga Yogyakarta, 2011.

[4] D. Permatasari, "Sistem Informasi Geografis Berbasis Android Untuk Pemetaan Industri Kecil di Kabupaten Bantul", Jurnal Penelitian Program Studi Teknik Informatika, Fakultas Sains dan Teknologi UIN Sunan Kalijaga Yogyakarta, 2013.

[5] H. T. Ramadhani, "Rancang Bangun Sistem Informasi Geografis Industri Kecil Dan Menengah Kabupaten Deli Serdang Berbasis Android", Jurnal Penelitian Jurusan Teknik Informatika Sekolah Tinggi Teknik Harapan Medan.

[6] S. Sadono," Pengantar Teori Ekonomi", Edisi Kedua, Jakarta: PT. Karya Grafindo Persada, 1995.

[7] Menteri Perindustrian Republik Indonesia, Peraturan Menteri Perindustrian Republik Indonesia Tentang Besaran Jumlah Tenaga Kerja dan Nilai Investasi untuk Klasifikasi Usaha Industri, 2016.

[8] Badan Pusat Statistik, "Klasifikasi Baku Lapangan Usaha Indonesia", Tersedia di https://spkonline.bps.go.id/spkonline/help/klasifika si/2 diakses pada 20-03-2019, 2016.

[9] Codelgniter, "Panduan Pengguna Codelgniter Indonesia", Tersedia di https://codeigniterid.github.io/user-guide/ diakses pada 13-01-2019, 2014.

[10] Android Studio, "Mengenal Android Studio", https://developer.android.com, diakses pada 1301-2019, 2014.

[11] D. Booth, et al, Web Services Architecture, https://www.w3.org/TR/ws-arch/\#whatis, diakses pada tanggal 13-01-2019, 2004.

[12] R. A. Sukamto, dan M. Shalahuddin., "Modul Pembelajaran Rekayasa Perangkat Lunak(Terstruktur dan Beorientasi Objek)", Bandung: Modula, 2011. 